\title{
Pengaruh Model Pembelajaran dan Motivasi Belajar Fisika terhadap Hasil Belajar Fisika (Studi Eksperimen Peserta Didik pada Kelas VIII SMP Negeri 40 Bulukumba)
}

\author{
Gustina $^{1}$, Sidin $\mathrm{Ali}^{2}$ \\ ${ }^{1}$ Universitas Tadulako \\ ${ }^{2}$ Universitas Negeri Makassar \\ 'gustina_spd@yahoo.com
}

\begin{abstract}
ABSTRAK
Telah dilakukan penelitian yang bertujuan untuk mengetahui : (1) apakah terdapat perbedaan hasil belajar fisika antara peserta didik yang diajar dengan model pembelajaran kontekstual dan konvensional pada kelas VIII SMP Negeri 40 Bulukumba (2) apakah terdapat perbedaan hasil belajar fisika antara peserta didik dengan motivasi belajar fisika tinggi yang diajar melalui model pembelajaran kontekstual dan konvensional pada kelas VIII SMP Negeri 40 Bulukumba (3) apakah terdapat perbedaan hasil belajar fisika antara peserta didik dengan motivasi belajar fisika rendah yang diajar melalui model pembelajaran kontekstual dan konvensional pada kelas VIII SMP Negeri 40, dan (4) apakah terdapat pengaruh interaksi antara model pembelajaran dengan motivasi belajar fisika terhadap hasil belajar fisika peserta didik pada kelas VIII SMP Negeri 40. Penelitian ini merupakan penelitian eksperimen yang menggunakan desain faktorial $2 \times 2$. Pengumpulan data dilakukan dengan menggunakan tes dan nontes. Data selanjutnya dianalisis dengan menggunakan analisis deskriptif dan inferensial secara manual dan dilengkapi dengan perhitungan menggunakan program IBM SPSS versi 20 for Windows. Pengujian hipotesis dilakukan pada taraf signifikansi $5 \%$ atau $\alpha=0,05$. Hasil penelitian menunjukkan bahwa : (1) secara keseluruhan, terdapat perbedaan hasil belajar fisika antara peserta didik yang diajar dengan model pembelajaran kontekstual dan konvensional pada kelas VIII SMP Negeri 40 Bulukumba (2) untuk motivasi belajar fisika tinggi, terdapat perbedaan hasil belajar fisika antara peserta didik yang diajar melalui model pembelajaran kontekstual dan konvensional pada kelas VIII SMP Negeri 40 Bulukumba (3) untuk motivasi belajar fisika rendah, terdapat perbedaan hasil belajar fisika antara peserta didik yang diajar melalui model pembelajaran kontekstual dan konvensional pada kelas VIII SMP Negeri 40 Bulukumba dan (4) terdapat pengaruh interaksi antara model pembelajaran dengan motivasi belajar fisika terhadap hasil belajar fisika peserta didik pada kelas VIII SMP Negeri 40.
\end{abstract}

Kata Kunci: Model Pembelajaran, Motivasi Belajar Fisika, dan Hasil Belajar Fisika.

\section{PENDAHULUAN}

Pendidikan merupakan salah satu aspek yang memegang peranan penting dalam pembangunan nasional. Untuk itu pendidikan seharusnya mendorong manusia terlibat dalam proses ke arah yang lebih baik dalam meningkatkan sumber daya manusia Indonesia yang beriman dan bertaqwa kepada Tuhan Yang Maha Esa, berbudi pekerti luhur, mandiri, maju, cerdas, kreatif, terampil, bertanggung jawab, dan produktif, serta sehat jasmani dan rohani. Sehingga pendidikan mampu berfungsi sebagai upaya dalam meningkatkan kualitas hidup pribadi maupun masyarakat.
Untuk mewujudkan hal tersebut, perlu diadakan peningkatan kualitas pendidikan dalam salah satu wadah pendidikan yaitu melalui pendidikan formal di sekolah. Hal tersebut dapat ditempuh dengan beberapa cara, seperti peningkatan bekal awal peserta didik, peningkatan kompetensi guru, peningkatan isi kurikulum, pembaharuan kualitas pembelajaran dan hasil belajar, penyediaan sarana dan prasarana belajar, dan sebagainya. Melalui berbagai cara tersebut, guru menduduki posisi yang sangat strategis dan akan berdampak positif terhadap penentuan keberhasilan dan proses pendidikan dan pembelajaran. Guru mempunyai tugas dan tanggung jawab yang luas, bukan 
hanya sebagai pengajar, tetapi sekaligus sebagai pendidik dan pembimbing peserta didik. Dalam proses kegiatan pembelajaran di sekolah juga dilaksanakan pembinaan kepribadian peserta didik agar menjadi manusia Indonesia sesuai dengan tujuan pendidikan nasional.

Menurut Baharuddin (2007:19) banyak faktor yang mempengaruhi keberhasilan proses belajar. Pertama, faktor yang berasal dari dalam diri peserta didik (faktor internal) yang meliputi keadaan jasmani, kecerdasan/intelegensi, motivasi, minat, sikap, dan bakat. Kedua, faktor yang berasal dari luar peserta didik (faktor eksternal) yang meliputi lingkungan sosial sekolah, lingkungan sosial masyarakat, lingkungan sosial keluarga, lingkungan alamiah, metode mengajar, kurikulum, disiplin sekolah serta sarana dan prasarana sekolah. Kedua faktor ini berpengaruh satu sama lain sehingga keduaduanya haruslah terpenuhi agar peserta didik dapat belajar dengan baik.

Berdasarkan studi pendahuluan yang dilakukan di SMP Negeri 40 pada kelas VII, guru dalam proses pembelajaran fisika masih seringkali terlalu teoritis dan kurang kontekstual. Proses pembelajaran umumnya cenderung dimulai dengan penyampaian informasi berupa definisi, pengertian-pengertian dari suatu obyek abstrak yang dituliskan dalam bentuk rumusrumus lalu diikuti contoh-contoh soal, kemudian diakhiri dengan latihan soal-soal. Konsep fisika yang seharusnya dikuasai peserta didik telah bergeser menjadi hafalan teori dan rumus-rumus semata. Sehingga peserta didik menganggap mempelajari fisika dinilai sulit sebab selain membutuhkan hafalan teori juga membutuhkan kemampuan matematika yang baik, akibatnya sebagian besar peserta didik kurang termotivasi dalam mempelajari fisika. Alasan tersebut akan mempengaruhi hasil belajar fisika peserta didik tidak mencapai tingkat ketuntasan yang diharapkan.

Proses belajar yang cenderung hanya mengarahkan peserta didik untuk menghafalkan materi membuat peserta didik kurang memahami materi yang dipelajarinya dan tidak mampu mengaplikasikannya dalam kehidupan sehari-hari. Materi pelajaran yang diberikan di sekolah hanya digunakan untuk menjawab soalsoal ujian yang diberikan oleh guru dan setelah ujian berakhir materi yang disampaikanpun perlahan-lahan hilang dari ingatan peserta didik. Saat soal diberikan dalam bentuk yang berbeda dari contoh soal, peserta didik akan kesulitan untuk menjawab soal tersebut.

Selama proses pembelajaran berlangsung di kelas, aktivitas utama yang dilakukan peserta didik adalah lebih banyak mendengar informasi guru. Informasi hanya diterima satu arah yakni hanya dari guru dan aktivitas belajar peserta didik cenderung pasif dalam pembelajaran. Bila guru mengajukan pertanyaan yang mau hanya satu atau dua orang peserta didik yang memberi respon, peserta didik tersebut akan memberi respon bila ditunjuk langsung oleh guru, selain itu peserta didik kurang percaya diri mengemukakan pendapat atau analisisnya pada guru sehingga peserta didik sudah dianggap memahami isi materi, serta memiliki perhatian yang kurang optimal dalam pembelajaran. Hal ini akan berdampak pada banyaknya peserta didik belum mencapai ketuntasan hasil belajar yang diharapkan karena pembelajaran yang disampaikan oleh guru tidak bermakna.

Peserta didik di kelas VIII SMP Negeri 40 Bulukumba belum sepenuhnya mencapai hasil belajar yang diharapkan seperti yang ditunjukkan pada Kriteria Ketuntasan Minimal $(\mathrm{KKM})$ mata pelajaran fisika $=65$. Kriteria Ketuntasan Minimal (KKM) Kompetensi dasar sebelumnya di kelas VII semester ganjil tahun ajaran 2011/2012 pada pokok bahasan Gerak yaitu 65. Presentase rata-rata hasil belajar fisika peserta didik secara klasikal hanya 67\% yang tuntas dan selebihnya 33\% memperoleh skor di bawah KKM KD 65 dengan tingkat penguasaan materi rendah sehingga tergolong kategori tidak tuntas.

Untuk mengantisipasi keadaan tersebut, maka guru sangat memegang peranan penting untuk mengupayakan model pembelajaran yang memungkinkan peserta didik memahami dan menguasai pelajaran fisika. Salah satu model pembelajaran yang tepat untuk diterapkan ialah model pembelajaran kontekstual, dengan meninjau motivasi belajar peserta didik. Motivasi 
belajar merupakan faktor psikis yang bersifat non-intelektual. Peranannya yang khas adalah dalam hal penumbuhan gairah, merasa senang dan semangat untuk belajar. Sehingga motivasi merupakan salah satu unsur penting dalam keberhasilan proses belajar. Motivasi tidak hanya penting untuk menjadikan seorang peserta didik terlibat dalam proses pembelajaran, tetapi juga penting dalam menentukan seberapa jauh peserta didik tersebut akan belajar dan memperoleh (mengkonstruksi) pengetahuan dari suatu proses pembelajaran. Peserta didik yang termotivasi untuk belajar, akan menggunakan proses kognitif yang lebih tinggi dalam belajar, sehingga pengetahuan yang diperolehnya juga akan lebih baik dan akan memperoleh hasil belajar yang optimal.

Pada prinsipnya, menurut Trianto (2007:103) model pembelajaran kontekstual (Contextual teaching and learning) adalah konsep belajar yang membantu guru mengaitkan antara materi yang diajarkannya dengan situasi dunia nyata peserta didik dan mendorong peserta didik membuat hubungan antara pengetahuan yang dimilikinya dengan penerapannya dalam kehidupan mereka sehari-hari. Selanjutnya Materi pelajaran akan tambah berarti jika peserta didik mempelajarai materi pelajaran yang disajikan melalui konteks kehidupan mereka, dan menemukan arti di dalam proses pembelajarannya, sehingga pembelajaran akan menjadi lebih berarti dan menyenangkan. Peserta didik akan bekerja keras untuk mencapai tujuan pembelajaran, mereka menggunakan pengalaman dan pengetahuan sebelumnya untuk membangun pengetahuan baru. Dan, selanjutnya peserta didik memanfaatkan kembali pemahaman pengetahuan dan kemampuannya itu dalam berbagai konteks di luar sekolah untuk menyelesaikan masalah dunia nyata yang kompleks, baik secara mandiri ataupun dengan berbagai kombinasi dan struktur kelompok".

Dalam model pembelajaran kontekstual ini, proses pembelajaran berlangsung secara alamiah dalam kegiatan peserta didik bekerja dan mengalami, serta peserta didik dapat mengembangkan pikirannya dan bukan hanya sekedar hafalan. Beberapa penelitian yang telah ada menyimpulkan bahwa model pembelajaran kontekstual dapat meningkatkan hasil belajar fisika peserta didik antara lain : (1) Model pembelajaran kontekstual dapat meningkatkan hasil belajar fisika peserta didik (Purnamasari, 2011:73) (2) Model pembelajaran kontekstual juga dapat digunakan dalam pencapaian aktivitas dan hasil belajar fisika peserta didik (Paramita, 2012:97).

Berdasarkan uraian di atas, maka penulis mencoba melakukan penelitian dengan judul "Pengaruh Model Pembelajaran dan Motivasi Belajar Terhadap Hasil Belajar Fisika Peserta didik SMP Negeri 40 Bulukumba”.

\section{Balajar}

Belajar bukan hanya sekedar menghapal, melaikan suatu proses mental yang terjadi dalam diri seseorang. Dalam konteks inilah belajar bisa bermakna sesuai dengan hakikat belajar sebagai suatu proses untuk mencapai tujuan. Belajar adalah suatu proses, yang merupakan langkahlangkah atau prosedur yang ditempuh (Hamalik, 2001:29). Proses belajar terjadi secara abstrak, karena terjadi secara mental dan tidak dapat diamati. Oleh karena itu, proses belajar hanya dapat diamati jika ada perubahan perilaku dari seseorang yang berbeda dengan sebelumnya. Perubahan tersebut bisa dalam hal pengetahuan (kognitif), sikap (afektif), dan keterampilannya (psikomotor). Jadi, belajar adalah suatu proses usaha yang dilakukan individu untuk memperoleh perubahan tingkah laku yang baru secara keseluruhan sebagai hasil pengalaman individu itu sendiri dalam interaksi dengan lingkungannya. Hasil interaksi tersebut berupa perubahan tingkah laku seperti pengetahuan, sikap, kebiasaan, keterampilan, kompetensi, dan sebagainya. sehingga dapat memberikan kontribusi terhadap pengembagan kualitas hidupnya.

\section{Pembelajaran}

Gagne mendifinisikan istilah pembelajaran sebagai serangkaian aktivitas yang sengaja diciptakan dengan meksud untuk memudahkan terjadinya proses belajar. Sedangkan Smit \& Ragan (1993) dalam Pribadi (2009:9) mengemukakan bahwa pembelajaran adalah pengembangan dan penyampaian informasi dari 
kegiatan yang diciptakan untuk memfasilitasi pencapaian tujuan yang spesifik. Jadi, pembelajaran adalah proses yang sengaja dirancanakan untuk menciptakan terjadinya aktivitas belajar dalam diri individu yang bersifat eksternal dan sengaja dirancang untuk mendukung terjadinya proses belajar internal dalam diri individu.

\section{Model pembelajaran Kontekstual}

Menurut Nurhadi (2002), pembelajaran kontekstual (contextual teaching and learning) merupakan konsep belajar yang dapat membantu guru mengaitkan antara meteri yang diajarkannya dengan situasi dunia nyata peserta didik dan mendorong peserta didik membuat hubungan antara pengetahuan yang dimilikinya dengan penerapannya dalam kehidupan mereka sebagai anggota keluarga dan masyarakat (Rusman, 2012:189).

Pembelajaran kontekstual memiliki tujuh komponen utama, yaitu konstruktivisme (contructivism), inkuiri (Inquiry), bertanya (questioning), masyarakat belajar (learning community), pemodelan (modeling), refleksi (reflection), dan penilaian autentik (authentic Assesment). Pembelajaran kontekstual dapat diterapkan dalam kurikulum apa saja, bidang studi apa saja, dan kelas bagaimanapun keadaannya (Depdiknas, 2002) dalam Trianto (2009:111).

Dalam penelitian ini, pembelajaran kontekstual merupakan sebuah model dalam pembelajaran yang dirancang untuk mengaitkan antara isi materi yang dipelajari oleh peserta didik di sekolah dengan situasi nyata kehidupan sehari-hari, untuk menemukan makna materi tersebut.

\section{Motivasi Belajar Fisika}

Motivasi merupakan salah satu unsur penting dalam belajar dan pembelajaran. Peserta didik yang memiliki motivasi belajar yang tinggi akan sangat membantu untuk dapat serius mempelajari sesuatu. Peserta didik yang memotivasi belajarnya rendah mungkin saja belajar sesuatu karena terpaksa dan tidak menganggap belajar sebagai kebutuhan. Motivasi tidak hanya penting untuk menjadikan seorang peserta didik terlibat dalam kegiatan belajar.
Tetapi juga penting dalam menentukan seberapa jauh peserta didik tersebut akan belajar dari suatu kegiatan pembelajaran atau seberapa jauh peserta didik tersebut memperoleh (mengkonstruksi) pengetahuan dalam suatu kegiatan pembelajaran. Peserta didik yang termotivasi untuk belajar sesuatu, akan menggunakan proses kognitif yang lebih tinggi dalam belajar, sehingga pengetahuan yang diperolehnya juga akan lebih baik.

Dilihat dari segi sumber munculnya, maka motivasi dapat dibedakan atas 2(dua) jenis, yakni:

\section{Motivasi Intrinsik (Motivasi Internal)}

Motivasi intrinsik merupakan motivasi yang tercakup di dalam situasi belajar dan memenuhi kebutuhan serta tujuan-tujuan peserta didik. Motivasi ini muncul dari dalam diri peserta didik sendiri (motivasi murni). Motivasi ini meliputi : (1) minat belajar; (2) harapan dan citacita masa depan; (3) keuletan menghadapi kesulitan; (4) rasa ingin tahu; (5) tekun menghadapi tugas; (6) adanya kemandirian; dan (7) adanya hasrat/ keinginan berhasil.

\section{Motivasi Ekstrinsik (Motivasi Eksternal)}

Motivasi ekstrinsik merupakan motivasi yang disebabkan oleh faktor-faktor dari luar situasi belajar. motivasi belajar ekstrinsik, meliputi: (1) pemberian hadiah dan pujian (reinforcement positif); (2) pemberian angka; (3) pemberian hukuman (reinforcement negatif); (4) adanya perhatian dari orang lain; (5) adanya saingan/ kompetisi; (6) adanya ulangan; dan (7) kondisi dan lingkungan belajar. Motivasi ekstrinsik juga dapat di artikan sebagai bentuk motivasi yang didalamnya aktivitas belajar dimulai dan diteruskan berdasarkan dorongan dari luar yang tidak secara mutlak berkaitan dengan aktivitas belajar.

Berdasarkan uraian diatas maka dalam penelitian ini, motivasi belajar fisika yang akan diselelidiki adalah keseluruhan daya penggerak baik di dalam maupun di luar diri peserta didik yang menimbulkan kegiatan belajar, yang menjamin kelangsungan dari kegiatan belajar dan yang memberikan arah pada kegiatan belajar. Dengan mengacu pada jenis motivasi intrinsik dan motivasi ekstrinsik. 


\section{Hasil Belajar Fisika}

Hasil belajar fisika merupakan kemampuan yang dimiliki siswa setelah ia menemukan pengalaman belajar tentang fisika, yang mana hasil belajar tersebut dipengaruhi oleh dua faktor, yaitu faktor yang berasal dari dalam dan luar diri siswa (Asriyadin, dkk: 2016)

Menurut Bloom (dalam, Sudjana 2011:22) secara garis besar membagi hasil belajar menjadi 3 ranah, yaitu: 1) Ranah kognitif, berkenaan dengan hasil belajar, intelektual yang terdiri dari enam aspek, yakni pengetahuan atau ingatan, pemahaman, aplikasi, analisis, sintesis, dan evaluasi. Kedua aspek pertama disebut kognitif tingkat rendah dan keenam aspek berikutnya termasuk kognitif tingkat tinggi, 2) Ranah afektif, berkenaan dengan aspek yang terdiri dari lima aspek yakni penerimaan, jawaban atau reaksi, penilaian, organisasi dan internalisasi, 3) Ranah psikomotor, berkenaan dengan hasil belajar keterampilan, kemampuan bertindak. Ada enam aspek psikomotorik, yakni (a) gerakan refleks, (b) keterampilan gerakan dasar, (c) kemampuan perseptual, (d) keharmonisan atau ketepatan, (e) gerakan keterampilan kompleks, (f) gerakan ekspresif dan interpretatif.

Diantara ketiga ranah itu, rana kognitiflah yang paling banyak dinilai oleh para guru di sekolah karena berkaitan dengan kemampuan para peserta didik dalam menguasai isi bahan pengajaran. Hasil belajar tersebut nampak dalam perubahan tingkah laku secara tehnik dirumuskan dalam sebuah pernyataan verbal melalui tujuan pembelajaran (tujuan instruksional). Hasil belajar yang akan diselidiki pada penelitian ini adalah hanya pada aspek kognitif dalam ranah Bloom sesuai dengan tuntutan kompetensi dasar yang dijabarkan dalam indikator pencapaian kompetensi.

\section{METODE PENELITIAN}

\section{Jenis dan Variabel Penelitian}

Penelitian ini merupakan penelitian eksperimen dengan desain faktorial $2 \times 2$. Dimana melibatkan dua kelas yaitu kelas eksperimen dan kelas kontrol. Kelas eksperimen diberi perlakuan yaitu menggunakan model pembelajaran kontekstual. Kelas kontrol diberi perlakuan yaitu menggunakan

model

pembelajaran

konvensional.

Dalam penelitian ini ada beberapa variabel penelitian yang digunakan yaitu: 1) variabel bebas, variabel bebas dalam penelitian ini adalah model pembelajaran dengan menerapkan model pembelajaran kontekstual dan konvensional, 2) variabel moderator, variabel moderator dalam penelitian ini adalah motivasi belajar fisika yang dimiliki oleh peserta didik, yang terdiri dari motivasi belajar fisika tinggi dan motivasi belajar fisika rendah, 3) variabel tak bebas, variabel tak bebas dalam penelitian ini adalah hasil belajar fisika peserta didik yang ingin dicapai setelah mendapatkan suatu perlakuan.

\section{Tempat dan Waktu Penelitian}

Penelitian ini dilaksanakan di SMP Negeri 40 Bulukumba yang beralamat di Jln. Pendidikan No. D.120 Bontomanai Kec. Rilau Ale, Kab. Bulukumba, Propinsi Sulawesi Selatan-Makassar.

Penelitian ini dilaksanakan pada semester 2 tahun ajaran 2012/2013, di mulai pada bulan Februari 2013 dan berakhir pada bulan Mei 2013.

\section{Populasi dan Sampel}

Populasi dalam penelitian ini adalah peserta didik kelas VIII SMP Negeri 40 Bulukumba yang terdiri dari 7 kelas yaitu kelas VIII $_{\mathrm{A}}$ sampai kelas VIII $_{G}$ dengan jumlah peserta didik 238 orang.

Sampel dalam penelitian ini ditentukan dengan teknik simple random sampling (Rambang). Pada teknik simple random sampling ini sebenarnya menggunakan rambang peserta didik, akan tetapi hal ini dapat mengganggu proses pembelajaran di sekolah tersebut. Untuk itu hanya dilakukan rambang kelas. Rambang kelas dilakukan dengan cara mengundi kelas yang akan dijadikan sampel penelitian. Dan setelah dilakukan pengundian diperoleh dua kelas sampel penelitian yaitu kelas $\mathrm{VIII}_{\mathrm{B}}$ sebagai kelas eksperimen dengan jumlah peserta didik 34 orang dan kelas VIII $_{D}$ sebagai kelas kontrol dengan jumlah peserta didik 34 orang

\section{Desain Dan Rancangan Penelitian}

Penelitian ini menggunakan desain faktorial $2 \times 2$ yang merupakan modifikasi dari design true experiment.

Teknik Pengumpulan Data 
Teknik pengumpulan data yaitu menggunakan tes dan nontes. Teknik tes pada penelitian ini berbentuk tes tertulis (soal pilihan ganda) untuk mengukur hasil belajar fisika peserta didik dalam ranah kognitif diakhir perlakuan. Sedangkan teknik nontes dengan menggunakan kuesioner yang dilakukan sebelum proses pembelajaran berlangsung yang bertujuan untuk mengukur tingkat motivasi belajar fisika peserta didik.

\section{Instrumen Penelitian}

Kuesioner ini disusun dalam bentuk daftar pernyataan tertulis yang pilihan jawabannya telah disediakan sehingga peserta didik akan memberikan tanda centang $(\sqrt{ })$ pada salah satu pilihan jawaban tersebut. Pernyataan pada kuesioner ini terdiri atas pernyataan positif $(+)$ dan negatif $(-)$ dan format pilihan jawaban didasarkan pada skala model Likert. Yang terdiri atas 5 (lima) pilihan yang memuat alternatif pilihan jawaban: Selalu (SL); Sering (SR); Kadang-Kadang (KK); Jarang (JR); dan Tidak Pernah (TP).

Untuk menentukan pembagian kategori motivasi belajar fisika tinggi dan rendah peserta didik sesuai dalam rancangan penelitian ini, maka digunakan pembagian berdasarkan distribusi kurva normal yaitu dipilih 27\% dari kelompok peserta didik untuk motivasi belajar fisika dan 27\% dari kelompok peserta didik untuk motivasi belajar fisika rendah. Dengan pembagian berikut: 1) Motivasi belajar fisika tinggi $\mathrm{X}>\overline{\mathrm{X}}+\frac{1}{2} S$; 2) Motivasi belajar fisika rendah $\mathrm{X}<\overline{\mathrm{X}}-\frac{1}{2} S$

Keterangan:

$\mathrm{X}$ : skor motivasi belajar fisika peserta didik

$\overline{\mathrm{X}}$ : rata-rata skor total motivasi belajar fisika peserta didik

Std : standar deviasi

\section{Tes Hasil Belajar fisika}

Tes hasil belajar fisika peserta didik disusun dalam tes tertulis berbentuk pilihan ganda. Item pilihan jawaban berjumlah 4 (empat) buah dengan simbol pilihan A, B, C, dan D. Setiap butir soal (item) hanya memiliki satu pilihan jawaban yang benar. Jika peserta didik menjawab benar mendapatkan skor 1 (satu) dan jika salah mendapatkan skor 0 (nol).

\section{Teknik Analisis Data}

\section{Analisis Uji Coba Instrumen Penelitian}

Analisis instrumen secara teoretis yang dilakukan dalam penelitian ini ialah menggunakan analisis Gregory berupa model kesepakatan antar penilai untuk validitas isi instrumen (Ruslan, 2009:19).

\section{Analisis inferensial}

Sebelum menggunakan analisis variansi (Anava) ini maka terlebih dahulu harus dilakukan uji prasyarat analisis yaitu uju normalitas dan uji homogenitas

Untuk menguji hipotesis pada penelitian ini, maka dilakukan analisis variansi (anava) dua jalan pada efek utama (main affect) dengan menghitung jumlah kuadrat (JK), derajat kebebasan (Dk), rata-rata jumlah kuadrat (RJK), $F$ hitung, dan F tabel (Purwanto, 2010:214). Setelah dilakukan analisis variansi (anava) dua jalan dan hasil hipotesis yang diperoleh yaitu hipotesis nol ditolak (Ho ditolak) atau hipotesis satu diterima $\left(\mathrm{H}_{1}\right.$ diterima), maka dilakukan uji lanjut anava sebagai tindak lanjut dari analisis variansi. Uji lanjut anava ini bertujuan untuk melakukan pengecekan terhadap rerata (mean) setiap pasangan kolom, pasangan baris, dan pasangan sel. Sehingga diketahui pada bagian mana sajakah terdapat rerata (mean) yang berbeda secara signifikan maupun tidak signifikan. Apabila sampel setiap kelompok berjumlah sama (sel sama) maka dapat digunakan uji Tukey, namun apabila jumlah sampel setiap kelompok tidak sama (sel tidak sama) maka digunakan uji Scheffe.

\section{HASIL DAN PEMBAHASAN \\ Analisis Deskriptif}

Hasil analisis deskriptif motivasi belajar fisika peserta didik kelas eksperimen $\left(\mathrm{VIII}_{\mathrm{B}}\right)$ dan kelas kontrol $\left(\right.$ VIII $\left._{D}\right)$ SMP Negeri 40 Bulukumba sebelum diberi perlakuan dengan menerapkan model pembelajaran kontekstual dan konvensional, dapat dipaparkan sebagai berikut.

Tabel 1. Statistik Skor Motivasi Belajar fisika Peserta Didik Kelas Eksprimen dan Kontrol 


\begin{tabular}{lcc}
\hline \multicolumn{1}{c}{ Deskriptif } & KE & KK \\
\hline Skor ideal & 280 & 280 \\
\hline $\begin{array}{l}\text { Skor } \\
\text { maksimum }\end{array}$ & 230 & 198 \\
\hline Skor minimum & 122 & 120 \\
\hline Jumlah sampel & 34 & 34 \\
\hline Rata-rata skor & 176,24 & 164,03 \\
\hline Standar deviasi & 22,38 & 19,29 \\
\hline
\end{tabular}

Berdasarkan tabel 1 deskriptif motivasi belajar fisika tersebut, terlihat bahwa kelas eksperimen memiliki rata-rata motivasi belajar lebih fisika tinggi dari pada kelas kontrol. Untuk pembagian kategori motivasi belajar fisika tinggi dan rendah pada peserta didik kelas eksperimen dan kelas kontrol, maka digunakan pembagian berdasarkan kategori kurva normal. Sehingga diperoleh deskripsi data motivasi belajar fisika untuk tiap sel desain penelitian pada tabel 4(2) berikut.

Tabel 2. Jumlah Sebaran Peserta Didik untuk tiap Kelompok Sel

\begin{tabular}{cccc}
\hline Motivasi & \multicolumn{2}{c}{ Model Pembelajaran } & Jumlah \\
\cline { 2 - 4 } Belajar Fisika & Kontekstual & Konvensional & \\
\hline Tinggi & 10 & 10 & 20 \\
\hline Rendah & 10 & 10 & 20 \\
\hline
\end{tabular}

Hasil analisis deskriptif hasil belajar fisika peserta didik kelas eksperimen setelah diajar model pembelajaran kontekstual dan kelas kontrol setelah diajar model pembelajaran konvensional dapat dipaparkan sebagai berikut:

Tabel 3. Statistik Skor Hasil Belajar Fisika

\begin{tabular}{lcc}
\hline \multicolumn{1}{c}{ Deskriptif } & KE & KK \\
\hline Skor ideal & 34 & 34 \\
\hline Skor maksimum & 32 & 29 \\
\hline Skor minimum & 19 & 16 \\
\hline Jumlah sampel & 34 & 34 \\
\hline Banyak kelas interval & 5 & 5 \\
\hline Rentang skor & 13 & 13 \\
\hline Panjang kelas interval & 3 & 3 \\
\hline Rata-rata skor & 25,00 & 22,09 \\
\hline Standar deviasi & 2,85 & 2,91 \\
\hline
\end{tabular}

Dalam penelitian ini, peserta didik diberikan tes secara keseluruhan yaitu 34 orang pada masing-masing kelas. Oleh karena penelitian ini memperhatikan variabel moderator yaitu motivasi belajar fisika yang diasumsikan juga turut mempengaruhi variabel tak bebas yaitu hasil belajar fisika, maka untuk keperluan pengujian hipotesis, terlebih dahulu dilakukan penentuan kelompok berdasarkan pembagian kategori distribusi kurva normal yang terdiri atas $27 \%$ dari 34 peserta didik (10 peserta didik) dengan motivasi belajar fisika tinggi dan $27 \%$ dari 34 peserta didik (10 peserta didik) dengan motivasi belajar fisika rendah. Data pembagian kategori inilah yang akan digunakan untuk keperluan analisis pengujian hipotesis. Untuk itu, peneliti juga memberikan penjelasan mengenai data tersebut, yaitu masing-masing 20 orang sampel pada kelas penelitian yang dipaparkan sebagai berikut.

Tabel 4. Statistik Skor Hasil Belajar Fisika Peserta

Didik Berdasarkan Kategori Motivasi Belajar Fisika

\begin{tabular}{clcc}
\hline \multirow{2}{*}{ Motivasi Belajar Fisika } & \multicolumn{2}{c}{ Kelompok } \\
\cline { 2 - 4 } & Skor ideal & 34 & 34 \\
\hline \multirow{4}{*}{ Tinggi } & Jumlah sampel & 10 & 10 \\
\cline { 2 - 4 } & Skor maksimum & 32 & 29 \\
\cline { 2 - 4 } & Skor minimum & 24 & 24 \\
\cline { 2 - 4 } & Skor rata-rata & 27,20 & 25,50 \\
\cline { 2 - 4 } & Standar deviasi & 2,35 & 1,58 \\
\cline { 2 - 4 } Rendah & Varians & 5,51 & 2,50 \\
\cline { 2 - 4 } & Jumlah sampel & 10 & 10 \\
\cline { 2 - 4 } & Skor maksimum & 30 & 21 \\
\cline { 2 - 4 } & Skor minimum & 19 & 16 \\
\cline { 2 - 4 } & Skor rata-rata & 23,50 & 18,8 \\
\cline { 2 - 4 } & Standar deviasi & 3,03 & 1,48 \\
\cline { 2 - 4 } & Varians & 9,17 & 2,18 \\
\hline
\end{tabular}

Berdasarkan tabel 4 di atas terlihat bahwa untuk motivasi belajar fisika tinggi, skor rata-rata hasil belajar fisika peserta didik pada kelompok eksperimen yaitu 27,2 dan lebih tinggi bila dibandingkan dengan kelompok kontrol yang hanya memperoleh skor 25,5 dengan standar deviasi masing-masing yaitu 2,35 dan 1,58. Sedangkan untuk motivasi belajar fisika rendah, skor rata-rata hasil belajar fisika peserta didik pada kelompok eksperimen yaitu 23,5 dan juga lebih tinggi bila dibandingkan dengan kelompok kontrol yang hanya memperoleh skor 18,8 dengan standar deviasi masing-masing yaitu 3,03 dan 1,48. Jika skor tersebut di konversi ke nilai, maka untuk motivasi belajar fisika tinggi peserta didik pada kelompok eksperimen memiliki nilai rata-rata 80,0 dan kelompok kontrol memiliki nilai 75,0. Sedangkan untuk motivasi belajar 
fisika rendah, kelompok eksperimen memiliki 69,1 dan kelompok kontrol memiliki nilai terendah 55,3.

\section{Analisis Inferensial}

\section{Analisis Prasyarat Analisis}

Pengujian normalitas data untuk kelas eksperimen dan kontrol dilakukan dengan menggunakan rumus Chi kuadrat, sehingga diperoleh hasil seperti diditunjukkan pada tabel 5 berikut.

Tabel 5. Uji Normalitas Data

\begin{tabular}{cccc}
\hline Kelas & $\chi_{\text {hitung }}^{2}$ & $\chi_{\text {tabel }}^{2}$ & Kesimpulan \\
\hline Eksperimen & 1,09 & 5,99 & Berdistribusi normal \\
\hline Kontrol & 0,27 & 5,99 & Berdistribusi normal \\
\hline
\end{tabular}

Berdasarkan tabel 5 dengan melihat nilai $X_{\text {hitung }}^{2}$ dan $X_{\text {tabel(0,95)(2) }}^{2}$, ternyata nilai $X_{\text {hitung }}^{2}<X_{\text {tabel }}^{2}$ $(0,95)(2)$ pada taraf nyata 0,05. Maka dapat disimpulkan bahwa data hasil belajar fisika peserta didik kelas eksperimen yang diajar dengan model pembelajaran kontekstual dan kelas kontrol yang diajar dengan model pembelajaran konvensioal berasal dari populasi yang berdistribusi normal.

Uji homogenitas bertujuan untuk mengetahui apakah sampel penelitian berasal dari populasi yang homogen atau tidak. Uji homogenitas pada penelitian ini dilakukan dengan menggunakan uji Harley Fmax. Sehingga diperoleh hasil seperti diditunjukkan pada tabel 6 berikut.

Tabel 6. Uji Homogenitas

\begin{tabular}{ccc}
\hline Fmax $_{\text {hitung }}$ & Fmax $_{\text {tabel }}$ & Kesimpulan \\
\hline 1,04 & 2,03 & Homogen \\
\hline
\end{tabular}

Berdasarkan tabel 6 dengan melihat nilai

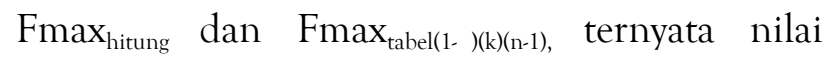
Fmax $_{\text {hitung }} \leq$ Fmax $_{\text {tabel (0,95)(3)(33) }}$ pada taraf nyata $\alpha=$ 0,05. Maka dapat disimpulkan bahwa data hasil belajar fisika peserta didik kelas kelas eksperimen yang diajar dengan model pembelajaran kontekstual dan kelas kontrol yang diajar dengan model pembelajaran konvensioal berasal dari populasi yang homogen.

Setelah pengujian prasyarat analisis data hasil belajar fisika menunjukkan bahwa semuanya telah memenuhi kriteria normalitas dan homogenitas. Maka tahapan selanjutnya dapat dilakukan yaitu pengujian hipotesis.

Pengujian Hipotesis Penelitian
Pengujian hipotesis pada penelitian ini bertujuan untuk mengetahui ada atau tidaknya perbedaan pengaruh model pembelajaran dan motivasi belajar fisika terhadap hasil belajar fisika serta interaksinya. Pengujian hipotesis menggunakan analisis varians (anava) dua jalan (2x2) dengan sel sama. Pengujian hipotesis penelitian juga dicocokkan dengan menggunakan program IBM SPSS versi 20 for windows melalui uji Tukey pada taraf signifikansi $\alpha=0,05$ untuk data yang sama yaitu sebanyak 20 sampel dari kelas eksperimen dan 20 sampel dari kelas kontrol. Pengujian hipotesis melalui program IBM SPPS versi 20 for windows diperoleh nilai $F_{\text {hitung }}$ yang menggambarkan perbedaan antar kolom, antar baris, dan interaksi antar sel, selain itu dilengkapi grafik yang menggambarkan interaksi antara kelompok yang dibandingkan, yaitu kelompok peserta didik yang diajar dengan model pembelajaran kontekstual dan konvensional yang memiliki motivasi belajar fisika tinggi dan motivasi belajar fisika rendah.

Berdasarkan hasil komputerisasi IBM SPSS versi 20 for windows melalui uji Tukey pada taraf signifikansi $\alpha=0,05$, diperoleh, maka hipotesis penelitian yaitu: 1) Corrected model, kita dapat mengetahui pengaruh semua variabel bebas secara bersama-sama terhadap variabel tak bebas. Jika nilai signifikansi corrected model $<0,05$ maka model valid. Dari tabel di atas terlihat bahwa signifikansinya lebih kecil dari 0,05 atau $0,000<0,05$ sehingga dapat disimpulkan bahwa model yang digunakan valid. Hal ini berarti bahwa, semua variabel model pembelajaran dan motivasi belajar fisika, serta interaksi antara model pembelajaran dan motivasi belajar fisika secara bersama-sama berpengaruh terhadap variabel hasil belajar fisika peserta didik; 2) Intercept, kita dapat mengetahui perubahan variabel dependen tanpa perlu dipengaruhi keberadaan variabel independen, atau dengan kata lain tanpa ada pengaruh variabel model pembelajaran, maka variabel hasil belajar fisika peserta didik dapat berubah nilainya. Apabila signifikansi $<0,05$ maka intercept signifikan. Dari tabel kita dapat melihat bahwa nilai signifikansi intercept lebih kecil dari 0,005 atau $0,000<0,05$ sehingga dapat disimpulkan bahwa intercept signifikan; 3) Kelompok_Perlakuan (model pembelajaran), berdasarkan tabel 4(13). di atas, memperlihatkan nilai signifikansi model 
pembelajaran sebesar 0,000 atau lebih kecil dari 0,05. $\mathrm{Hal}$ ini menyatakan bahwa pengaruh model pembelajaran terhadap hasil belajar fisika peserta didik di dalam penelitian ini berpengaruh secara signifikan; 4) Motivasi_Belajar_Fisika, berdasarkan tabel 4(13). di atas, memperlihatkan nilai signifikansi motivasi belajar sebesar 0,000 atau lebih kecil dari 0,05 . Hal ini menyatakan bahwa pengaruh motivasi belajar fisika terhadap hasil belajar fisika peserta didik pada penelitian ini berpengaruh secara signifikan; 5) Kelompok Perlakuan Motivasi Belajar Fisika, memperlihatkan pengaruh interaksi antara model pembelajaran dan motivasi belajar fisika terhadap hasil belajar fisika Peserta didik. Apabila nilai signifikansi Kelompok Perlakuan Motivasi Belajar Fisika < 0,05 maka ada pengaruh interaksi. Dari tabel 4(13). diperoleh nilai signifikansinya sebesar 0,038 atau lebih kecil dari 0,05. Sehingga dapat disimpulkan bahwa ada pengaruh interaksi antara model pembelajaran dan motivasi belajar fisika peserta didik terhadap hasil belajar. Hal ini dapat didukung dengan gambar profile plots berikut:

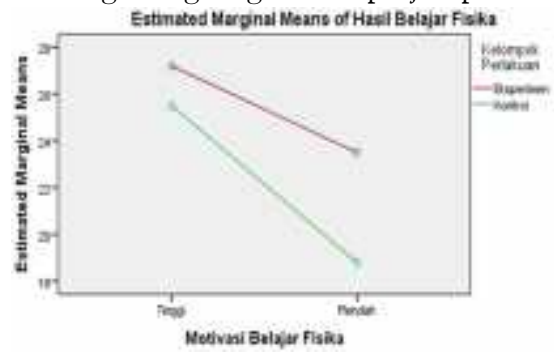

Gambar 1. Diagram Plot Interaksi Antar Variabel

Diagram gambar 1 di atas menunjukkan bahwa garis merah merupakan rentang rata-rata skor hasil belajar fisika yang diperoleh oleh kelompok eksperimen dengan rata-rata skor hasil belajar fisika untuk motivasi belajar fisika tinggi yaitu 27,2 dan untuk motivasi belajar fisika rendah yaitu 23,5. Sehingga untuk kelompok eksperimen memperoleh rentang rata-rata skor hasil belajar fisika sebesar 3,7. Sedangkan pada garis hijau merupakan rentang rata-rata skor hasil belajar fisika yang diperoleh oleh kelompok kontrol dengan rata-rata skor hasil belajar fisika untuk motivasi belajar fisika tinggi yaitu 25,5 dan untuk motivasi belajar fisika rendah yaitu 18,8. Sehingga untuk kelompok kontrol memperoleh rentang rata-rata skor hasil belajar fisika sebesar 6,7. Selain itu, kedua garis tersebut memperlihatkan ada ketidak sejajaran garis, jika kedua garis tersebut ditarik dan diperpanjang maka akan saling berpotongan satu sama lain.
Hal ini menandakan ada efek interaksi yang terjadi.

Uji lanjut anava yang dilakukan adalah uji Tukey, sebab seluruh kelompok mempunyai jumlah sampel yang sama. Uji Tukey dilakukan dengan cara membandingkan beda rerata (mean) dengan beda kritik. Berdasarkan hasil analisis data diperoleh hasil uji Tukey sebagai berikut.

Tabel 7. Ringkasan Rata-Rata (Mean) Hasil Belajar Fisika tiap Sel

\begin{tabular}{ccccc}
\hline Data & $\mathrm{A}_{1} \mathrm{~B}_{1}$ & $\mathrm{~A}_{1} \mathrm{~B}_{2}$ & $\mathrm{~A}_{2} \mathrm{~B}_{1}$ & $\mathrm{~A}_{2} \mathrm{~B}_{2}$ \\
\hline$\overline{\mathbf{X}}$ & 27,2 & 23,5 & 25,5 & 18,8 \\
\hline $\mathrm{N}$ & 10 & 10 & 10 & 10
\end{tabular}

Sehingga, perbandingan beda mean dengan beda kritik antar kelompok diperlihatkan pada tabel berikut.

Tabel 8. Rangkuman Beda Mean dan Beda Kritik Hasil Belajar Fisika

\begin{tabular}{cccc}
\hline Beda Mean & $\begin{array}{r}\text { Beda } \\
\text { Mean }\end{array}$ & $\begin{array}{c}\text { Beda } \\
\text { Kritik }\end{array}$ & Keputusan Uji \\
\hline$\overline{\mathbf{X}} \mathrm{A}_{1} \mathrm{~B}_{1}$ dan $\overline{\mathbf{X}} \mathrm{A}_{1} \mathrm{~B}_{2}$ & 3,70 & 2,65 & Signifikan \\
\hline$\overline{\mathbf{X}} \mathrm{A}_{2} \mathrm{~B}_{1}$ dan $\overline{\mathbf{X}} \mathrm{A}_{2} \mathrm{~B}_{2}$ & 6,70 & 2,65 & Signifikan \\
\hline$\overline{\mathbf{X}} \mathrm{A}_{1} \mathrm{~B}_{1}$ dan $\overline{\mathbf{X}} \mathrm{A}_{2} \mathrm{~B}_{1}$ & 1,70 & 2,65 & Tidak Signifikan \\
\hline$\overline{\mathbf{X}} \mathrm{A}_{1} \mathrm{~B}_{2}$ dan $\overline{\mathbf{X}} \mathrm{A}_{2} \mathrm{~B}_{2}$ & 4,70 & 2,65 & Signifikan \\
\hline$\overline{\mathbf{X}} \mathrm{A}_{1} \mathrm{~B}_{1}$ dan $\overline{\mathbf{X}} \mathrm{A}_{2} \mathrm{~B}_{2}$ & 8,40 & 2,65 & Signifikan \\
\hline$\overline{\mathbf{X}} \mathrm{A}_{2} \mathrm{~B}_{1}$ dan $\overline{\mathbf{X}} \mathrm{A}_{2} \mathrm{~B}_{2}$ & 6,70 & 2,65 & Signifikan \\
\hline
\end{tabular}

Berdasarkan tabel 4(15) di atas, diperoleh kesimpulan mengenai hipotesis yang diajukan, yaitu sebagai berikut: 1) Perbandingan $A_{1} B_{1}$ dan $\mathrm{A}_{2} \mathrm{~B}_{1}$ (Hipotesis kedua), Untuk motivasi belajar fisika tinggi, terdapat perbedaan hasil belajar fisika yang tidak signifikan antara peserta didik yang diajar melalui model pembelajaran kontekstual dan konvensional pada kelas VIII SMP Negeri 40 Bulukumba. Hal ini terlihat dari beda mean lebih kecil dari beda kritik atau 1,70 $<2,65 ; 2)$ Perbandingan $A_{1} B_{2}$ dan $A_{2} B_{2}$ (Hipotesis ketiga), Untuk motivasi belajar fisika rendah, terdapat perbedaan hasil belajar fisika yang signifikan antara peserta didik yang diajar melalui model pembelajaran kontekstual dan konvensional pada kelas VIII SMP Negeri 40 Bulukumba. Hal ini terlihat dari beda mean lebih besar dari beda kritik atau 4,70>2,65.

\section{Pembahasan}

Penelitian ini dilaksanakan untuk mengetahui pengaruh model pembelajaran dan motivasi belajar fisika terhadap hasil belajar fisika peserta didik kelas VIII SMP Negeri 40 
Bulukumba. Yang mana membahas tentang (1) pengaruh model pembelajaran terhadap hasil belajar fisika peserta didik,(2) pengaruh motivasi belajar fisika terhadap hasil belajar fisika peserta didik, dan (3) pengaruh interaksi antara model pembelajaran dan motivasi belajar fisika terhadap hasil belajar fisika peserta didik. Berdasarkan hasil pengujian hipotesis penelitian terlihat bahwa seluruh hipotesis yang diajukan dalam penelitian ini, menolak hipotesis nol (Ho ditolak) yang berarti ada perbedaan dan interaksi antara model pembelajaran dan motivasi belajar fisika terhadap hasil belajar fisika peserta didik. Rincian hasil hipotesis tersebut sebagai berikut.

Pengaruh Model Pembelajaran terhadap Hasil Belajar Fisika Peserta Didik

\section{Hipotesis Pertama}

Hasil penelitian menunjukkan bahwa terdapat perbedaan pengaruh model pembelajaran terhadap hasil belajar fisika peserta didik. Dengan kata lain, secara keseluruhan terdapat perbedaan hasil belajar fisika peserta didik yang diajar dengan model pembelajaran kontekstual dan konvensional pada kelas VIII SMP Negeri 40 Bulukumba. Hal ini terlihat dari hasil perhitungan analisis variansi (anava) dua jalan dengan sel sama yang menunjukkan $F_{\text {hitung }}>$ $\mathrm{F}_{\text {tabel }}$ yaitu 55,88 > 4,11 maka untuk hipotesis pertama, $\mathrm{H}_{0}$ ditolak pada taraf signifikasi $5 \%$ atau $\alpha=0,05$.

Peserta didik pada kelompok eksperimen yang diajar dengan model pembelajaran kontekstual proses pembelajarannya menggunakan lembar kegiatan peserta didik (LKPD) untuk membantu kegiatan menemukan makna materi yang dipelajari (kegiatan eksperimen di laboratorium). Setelah itu hasil dari lembar kegiatan peserta didik (LKPD) dinilai oleh guru kemudian dijadikan refleksi bagi peserta didik untuk melihat sejauh mana kekurangan maupun pencapaian dari hasil kinerja yang dilakukannya. Sedangkan peserta didik pada kelompok kontrol yang diajar dengan model pembelajaran konvensional proses pembelajarannya tanpa menggunakan lembar kegiatan peserta didik (LKPD), dimana seluruh informasi dan materi berasal dari guru. Hasil belajar yang diperoleh pada kelompok eksperimen lebih tinggi dibandingkan dengan kelompok kontrol. Fakta ini menunjukkan bahwa peserta didik yang diajar dengan menggunakan model pembelajaran kontekstual lebih mudah dalam mempelajari dan memahami konsep-konsep materi fisika yang di ajarkan dibandingkan dengan menggunakan model pembelajaran konvensional. Pada model pembelajaran kontekstual ini, peserta didik dapat mengkonstruksi sendiri pengetahuannya berdasarkan apa yang dipelajari dengan melakukan eksperimen secara langsung dan mengaitkannya pada peristiwa yang biasa dialaminya dalam kehidupan sehari-hari sehingga proses belajar lebih bermakna. Proses tersebut sejalan dengan pendapat Suparno (1997) (dalam Putra, 2012:12) bercirikan diantaranya belajar berarti membentuk makna, dan makna diciptakan oleh peserta didik dari apa yang mereka lihat, dengar, rasakan, dan alami. Sedangkan peserta didik yang diajar dengan menggunakan model pembelajaran konvensional kurang mengeksplor kemampuannya dan cenderung pasif dalam menggali dan menemukan konsep fisika yang dipelajari karena proses pembelajaran didominasi oleh guru dalam hal ini informasi materi maupun konsep-konsep fisika seluruhnya berasal dari guru.

Temuan penelitian ini sejalan dengan hasil penelitian sebelumnya, (1) Sanjayanti (2013) menemukan bahwa terdapat perbedaan antara model pembelajaran kontekstual dan konvensional terhadap keterampilan berpikir kreatif dan sikap ilmiah, (2) Lee (2010) menemukan bahwa terdapat pengaruh signifikan positif antara model pembelajaran terhadap prestasi belajar, dan (3) Mulyono (2010) menemukan bahwa terdapat perbedaan antara model pembelajaran kontekstual dan konvensional terhadap hasil belajar. Kesesuaian hasil penelitian ini dengan penelitian terdahulu memberikan penguatan bahwa pemilihan model pembelajaran yang tepat dapat mempengaruhi hasil belajar peserta didik.

Pengaruh Motivasi Belajar Terhadap Hasil Belajar Fisika Peserta Didik 
Hasil penelitian menunjukkan bahwa terdapat pengaruh motivasi belajar fisika terhadap hasil belajar fisika peserta didik. Dengan kata lain, untuk kelompok peserta didik dengan motivasi belajar fisika tinggi memperoleh hasil belajar lebih tinggi dibandingkan kelompok peserta didik yang memiliki motivasi belajar fisika rendah pada kelas VIII SMP Negeri Bulukumba. Hal ini terlihat dari hasil perhitungan analisis variansi (anava) dua jalan dengan sel sama yang menunjukkan $F_{\text {hitung }}>F_{\text {tabel }}$ yaitu 21,16> 4,11 maka untuk hipotesis kedua dan ketiga, $\mathrm{H}_{0}$ ditolak pada taraf signifikasi 5\% atau $\alpha=0,05$. Hal ini, dikuatkan dengan fakta bahwa peserta didik yang termotivasi untuk belajar fisika, akan menggunakan proses kognitif yang lebih tinggi dalam belajar fisika, sehingga pengetahuan yang diperolehnya juga akan lebih baik dan akan memperoleh hasil belajar fisika yang optimal. Peserta didik yang memiliki motivasi belajar fisika tinggi menampakkan minat dan perhatian penuh terhadap tugas-tugas belajar fisika. Mereka memusatkan energi fisik maupun psikis terhadap kegiatan, tanpa merasa bosan apalagi didukung oleh penggunaan model pembelajaran yang tepat yang mengaktifkan peserta didik. Peserta didik yang memiliki motivasi belajar fisika rendah menampakkan keengganan, cepat bosan, dan berusaha menghindar dari kegiatan belajar sehingga memperoleh hasil belajar fisika yang kurang optimal.

Temuan penelitian ini sejalan dengan hasil penelitian sebelumnya, (1) Putra (2012) menemukan bahwa terdapat perbedaan pengaruh antara motivasi belajar terhadap hasil belajar, (2) Lee (2010) menemukan bahwa motivasi belajar berpengaruh signifikan positif terhadap prestasi belajar, (3) Tella (2007) menemukan bahwa tingkat motivasi belajar berpengaruh terhadap hasil belajar. Kesesuaian hasil penelitian ini dengan penelitian terdahulu memberikan penguatan bahwa motivasi belajar dapat mempengaruhi hasil belajar peserta didik, peserta didik yang memiliki motivasi belajar tinggi akan memperoleh hasil belajar yang tinggi pula dan begitupula sebaliknya.

Hipotesis Kedua
Untuk melihat perbedaan tersebut secara signifikan atau tidaknya, maka dilakukan uji lanjut anava melalui uji Tukey. Uji Tukey ini membandingkan antara kelompok peserta didik dengan motivasi belajar fisika tinggi $\left(B_{1}\right)$ yang diajar dengan model pembelajaran kontekstual $\left(A_{1}\right)$ dan konvensional $\left(A_{2}\right)$ atau $A_{1} B_{1}$ banding $A_{2} B_{1}$. Sehingga dari hasil penelitian menunjukkan bahwa untuk motivasi belajar fisika tinggi, terdapat perbedaan hasil belajar fisika yang tidak signifikan antara peserta didik yang diajar dengan model pembelajaran kontekstual dan konvensional pada kelas VIII SMP Negeri 40 Bulukumba. Hal ini terlihat dari hasil perhitungan uji lanjut anava yang menunjukkan beda mean $\left(\mu_{1}\right)$ lebih kecil dari beda kritik $\left(\mu_{2}\right)$ atau $1,70<2,65$ pada taraf signifikasi $5 \%$ atau $\alpha=0,05$. Hal ini dikarenakan bahwa, proses pembelajaran dengan model pembelajaran kontekstual dan konvensional, guru sama-sama menggunakan media pembelajaran secara kontekstual (alat peraga) untuk mendukung penyampaian informasi materi maupun konsep-konsep fisika kepada peserta didik. Hanya saja pada model pembelajaran kontekstual, peserta didik secara langsung menggunakan media kontekstual tersebut dengan melakukan eksperimen secara langsung. Sedangkan pada model pembelajaran konvensional, penggunaan media pembelajaran kontekstual dilakukan sepenuhnya oleh guru dan peserta didik tidak terlibat langsung dalam penggunaannya. Sehingga untuk kelompok peserta didik yang memiliki motivasi belajar fisika tinggi pada setiap model pembelajaran diperoleh perbedan hasil belajar fisika yang tidak signifikan.

\section{Hipotesis Ketiga}

Sama halnya dengan hipotesis kedua, maka pada hipotesis ketiga ini untuk melihat perbedaan tersebut secara signifikan atau tidaknya dilakukan uji lanjut anava melalui uji Tukey. Uji lanjut Tukey ini membandingkan antara kelompok peserta didik dengan motivasi belajar fisika rendah $\left(\mathrm{B}_{2}\right)$ yang diajar dengan model pembelajaran kontekstual $\left(A_{1}\right)$ dan konvensional $\left(A_{2}\right)$ atau $A_{1} B_{2}$ banding $A_{2} B_{2}$. Sehingga dari hasil penelitian menunjukkan 
bahwa untuk motivasi belajar fisika rendah, terdapat perbedaan hasil belajar fisika yang signifikan antara peserta didik yang diajar dengan model pembelajaran kontekstual dan konvensional pada kelas VIII SMP Negeri 40 Bulukumba. Hal ini terlihat dari hasil perhitungan uji lanjut anava yang menunjukkan beda mean $\left(\mu_{1}\right)$ lebih besar dari beda kritik $\left(\mu_{2}\right)$ atau 4,70>2,65 maka untuk hipotesis ketiga $\mathrm{H}_{0}$ juga ditolak pada taraf signifikasi $5 \%$ atau $\alpha=$ 0,05 . Hal ini dikuatkan dengan fakta bahwa kelompok peserta didik yang memiliki motivasi belajar fisika rendah yang diajar dengan model pembelajaran kontekstual menunjukkan kemauan belajar fisika yang tinggi dan cenderung aktif dalam proses pembelajaran karena dengan model pembelajaran kontekstual ini, dapat menarik perhatian peserta didik untuk belajar fisika dan membangkitkan rasa ingin tahunya melalui keterlibatan langsung dalam proses pembelajaran yaitu pada kegiatan eksperimen. Sedangkan kelompok peserta didik yang memiliki motivasi belajar fisika rendah yang diajar dengan model pembelajaran konvensional menunjukkan kemauan belajar fisika yang rendah dan cepat merasa bosan sehingga peserta didik kurang aktif dalam proses pembelajaran fisika. Sehingga peserta didik yang memiliki motivasi belajar fisika rendah dan diajar dengan model pembelajaran yang kurang tepat (model pembelajaran konvensional) memperoleh hasil belajar fisika yang kurang optimal.

Pengaruh Interaksi antara Model Pembelajaran dan Motivasi Belajar Fisika terhadap Hasil Belajar Fisika Peserta Didik

\section{Hipotesis Keempat}

Hasil penelitian ini menunjukkan terdapat terdapat pengaruh interaksi antara model pembelajaran dan motivasi belajar fisika terhadap hasil belajar fisika peserta didik pada kelas VIII SMP Negeri 40 Bulukumba. Hal ini terlihat dari hasil perhitungan analisis variansi (anava) dua jalan dengan sel sama yang menunjukkan $\mathrm{F}_{\text {hitung }}>\mathrm{F}_{\text {tabel }}$ yaitu $4,656>4,11$ maka untuk hipotesis keempat $\mathrm{H}_{0}$ ditolak pada taraf signifikasi $5 \%$ atau $\alpha=0,05$. Hasil ini didukung dengan gambar plot estimasi marginal means hasil belajar fisika pada gambar 4(3) yang menunjukkan bahwa kelompok kontrol memiliki rentang rata-rata skor tertinggi dibandingkan kelompok eksperimen berdasarkan kategori motivasi belajar fisika, yang berarti bahwa model pembelajaran yang diterapkan dalam kelompok eksperimen dan kontrol sama-sama berpengaruh baik dalam pencapaian hasil belajar fisika pada kategori motivasi belajar fisika tinggi, akan tetapi jika dilihat dari kategori motivasi belajar fisika rendah model pembelajaran yang diterapkan pada kelompok eksperimen lebih unggul/baik dalam pencapaian hasil belajar fisika.

Selain itu, ada ketidaksejajaran garis, jika garis tersebut ditarik dan diperpanjang maka akan saling berpotongan satu sama lain menandakan terdapat interaksi. Dengan kata lain, pemberian perlakuan berupa model pembelajaran dan motivasi belajar fisika berinteraksi dalam menentukan variansi hasil belajar fisika peserta didik. Pemberian perlakuan dengan model pembelajaran yang berbeda memberikan pengaruh terhadap hasil belajar fisika pada tingkat motivasi belajar fisika yang berbeda. Hal ini diperkuat dengan fakta bahwa dengan model pembelajaran yang tepat serta didukung motivasi belajar fisika tinggi akan memberikan pengaruh positif terhadap pencapaian hasil belajar fisika peserta didik dan begitupula sebaliknya. Selain itu dengan model pembelajaran yang tepat dapat meningkatkan motivasi belajar fisika dan hasil belajar fisika peserta didik. Sehingga dapat dikatakan selain model pembelajaran, motivasi belajar fisika juga dapat menjadi salah satu faktor pendukung dan berpengaruh dalam pencapaian hasil belajar fisika peserta didik.

\section{Keterbatasan Penelitian}

Pada pelaksanaan penelitian ini sudah diupayakan semaksimal mungkin untuk mendapatkan hasil penelitian yang optimal dengan meminimalisir kekurangan terjadi. Namun penulis menyadari akan keterbatasan dalam penelitian ini, yaitu dalam pelaksanaan kegiatan eksperimen di kelas, diperlukan alat dan bahan percobaan yang menyesuaikan jumlah kelompok, akan tetapi persediaan

\section{KESIMPULAN}


Berdasarkan hasil penelitian dan pembahasan yang telah dikemukakan pada bab sebelumnya, maka dapat ditarik beberapa kesimpulan sebagai berikut: 1) Secara keseluruhan, terdapat perbedaan hasil belajar fisika antara peserta didik yang diajar dengan model pembelajaran kontekstual dan konvensional pada kelas VIII SMP Negeri 40 Bulukumba; 2) Untuk motivasi belajar fisika tinggi, terdapat perbedaan hasil belajar fisika peserta didik yang diajar melalui model pembelajaran kontekstual dan konvensional pada kelas VIII SMP Negeri 40 Bulukumba; 3) Untuk motivasi belajar fisika rendah, terdapat perbedaan hasil belajar fisika peserta didik yang diajar melalui model pembelajaran kontekstual dan konvensional pada kelas VIII SMP Negeri 40 Bulukumba 4) Terdapat pengaruh interaksi antara model pembelajaran dengan motivasi belajar fisika terhadap hasil belajar fisika peserta didik pada kelas VIII SMP Negeri 40 Bulukumba .

\section{DAFTAR PUSTAKA}

Ali,Sidin \& Khaeruddin. 2012. Evaluasi Pembelajaran. Makassar : Badan Penerbit UNM.

Arends, Richard. 1997. Classroom Instructional Management. New York : The McGraw-Hill Company.

Arikunto,Suharsimi. 1998. Prosedur Penelitian. Jakarta : PT Rineka Cipta.

Arikunto,Suharsimi. 2012. Dasar-Dasar Evaluasi Pendidikan. Jakarta : Bumi Aksara.

Baharuddin. 2007. Teori Belajar EF Pembelajaran. Jogjakarta : Ar-Ruzz Media.

Briggs, Leslie. 1987. The Process of Learning. Sidney : Prentice Hall of Australia Pty Ltd.

Dahar, Ratna Willis. 1996. Teori-teori Belajar. Jakarta. Erlangga

Dimyati \& Moedjiono, 2002. Belajar dan Pembelajaran. Jakarta: Rineka Cipta.

Hamalik, Oemar. 2001. Proses belajar Mengajar. Jakarta: Bumi Aksara.

Kardi \& Nur, Muhammad. 2000 . Pengajaran Langsung. Surabaya : Unesa

Karim, Saiful. 2008. Belajar Fisika Membuka Cakrawala Alam sekitar untk Kelas VIII
SMP/MTs. Jakarta: Departemen Pendidikan Nasional.

Lee, I-Chao. 2010. The Effect of Learning Motivation, Total Quality Teaching and Peer-Assisted Learning on Study Achievement: Empirical Analysis from Vocational Universities or Colleges' studentsin Taiwani. The Journal of Human Resource and Adult Learning, 6 (2):69

Mahfudy, Sofyan. 2011. Eksperimentasi Pembelajaran Contextual Teaching And Learning (Ctl) Dan Pembelajaran Langsung Yang Berbasis . Seminar Nasional Matematika Prodi Pendidikan Matematika, Universitas Muhammadiyah Surakarta, (p. 69). Surakarta: Universitas Muhammadiyah Surakarta.

Mulyono, Edy. 2010. Eksperimentas Pembelajaran metematika dengan penedekatan pembelajaran Kontekstual pada Pokok Bahasan Aritmetika Sosial ditinjau dari Motivasi Belajar Siswa kelas VII SMP di Kabupaten Sragen. Tesis. Surakarta : PPs UNS.

Nurhadi. 2002. Pendekatan Kontekstual (Contextual Teaching And Learning). Malang : Universitas Negeri Malang.

Paramita, Ielda. 2012. Pengembangan Perangkat Pembelajaran Fisika Berbasis Pendekatan Kontekstual Dalam Pencapaian Aktivitas dan Hasil Belajar Fisika Siswa Kelas X SMA Negeri 3 Palu. Tesis. Makassar : PPs UNM.

Purnamasari. 2011. Upaya Meningkatkan Hasil Belajar Fisika Melalui Pembelajaran dengan Menggunakan Pendekatan Contextual Teaching and Learning (CTL). Skripsi. Bandung : FPMIPA UPI.

Purwanto. 2010. Statistika Untuk Penelitian. Yogyakarta: Pustaka Pelajar.

Putra, Elpri Darta. 2012. Pengaruh Model Pembelajaran Kontekstual Terhadap Motivasi Belajar IPS Siswa Kelas IVB SDN 111 Pekanbaru. Jurnal : FKIP Universitas Riau

Pribadi, Benny. 2009. Model Desain Sistem Pembelajaran. Jakarta: Dian Rakyat

Ratumanan, Tanwey Gerson. 2003. Evaluasi Hasil Belajar yang relevan dengan Kurikulum Berbasis Kompetensi. Surabaya : Unesa University Press. 
Ratumanan, Tanwey Gerson. 2002. Belajar Dan Pembelajaran. Surabaya : Unesa University Press.

Ruslan. 2009. Validitas Isi. Buletin LPMP Sulawesi Selatan Pa'biritta Media Informasi $\&$ Komunikasi Pendidikan.

Rusman. 2012. Model-Model Pembelajaran Mengembangkan Profesionalisme Guru Edisi kedua. Jakarta : PT Rajagrafindo Persada.

Sardiman, A.M. 1986. Interaksi \&ु Motivasi Belajar Mengajar. Jakarta : PT Rajagrafindo Persada.

Sardiman, A.M. 2003. Interaksi Eु Motivasi Belajar Mengajar. Jakarta : PT Rajagrafindo Persada.

Sudjana, Nana. 2002. Dasar-dasar Proses Belajar Mengajar. Bandung : Sinar Baru Algesindo.

Sudjana, Nana. 2005. Metoda Statistik. Bandung : PT. Tarsito Bandung.

Sudjana, Nana. 2011. Penilaian Hasil Proses Belajar Mengajar. Bandung : PT Remaja Rosdakarya.

Sanjayanti, 2013. Pengaruh Model Contextual Teaching Learning Bermuatan Pendidikan Karakter Terhadap Keterampilan Berpikir Kreatif Dan Sikap Ilmiah Ditinjau Dari Motivasi Belajar. e-Journal Program Pascasarjana Universitas Pendidikan Ganesha Program Studi Pendidikan IPA, 3.

Sugiyono. 2012. Metode Penelitian Pendidikan. Bandung : Alfabeta.

Tella, Adedeji. 2007. The Impact of Motivation on Student's Academic Achievement and Learning Outcomes in Mathematics among Secondary School Students in Nigeria. Eurasia Journal of Mathematics, Science $\mathcal{E}$ Technology Education 3(2): 154-155.

Trianto, 2007. Model-Model Pembelajaran Inovatif Berorientasi Kontruktivistik. Jakarta : Prestasi Pustaka.

Trianto, 2009. Mendesain Model Pembelajaran Inovatif-Progresif. Jakarta : Kencana Prenada Group. 